\title{
Sexual Harassment and Candidate Evaluation: Gender and Partisanship Interact to Affect Voter Responses to Candidates Accused of Harassment
}

\author{
Natalie Masuoka ${ }^{1}$ (D) Christian Grose ${ }^{2} \cdot$ Jane Junn $^{2}$
}

Accepted: 23 November 2021

(C) The Author(s) 2021

\begin{abstract}
Public airing of incidents of sexual harassment have moved abuse from the shadows to the light, spurring mass response in the form of \#MeToo and "Time's Up." While sexual harassment holds negative valence, election outcomes suggest that not all voters punish leaders accused of harassment. We argue there is systematic variation in how voters respond to candidates accused of harassment because evaluations are made within the context of both partisanship and the gendered issue of sexual harassment. As a result, we expect to find distinct responses across four voter groupsDemocratic women and men, and Republican women and men on the specific issue of harassment. We present supporting evidence from two survey experiments and a third associational study to show that Democratic women are most likely to electorally punish sexual harassers. Experimental evidence also shows that Republican men are least likely to electorally punish candidates accused of harassment.
\end{abstract}

Keywords Gender · Partisanship · Political candidates · Scandal · Sexual harassment

The spate of revelations of sexual harassment by candidates for political office in recent years raises new questions about the extent to which these accounts influence voters. Typically understood as a person engaging in unwanted sexual advances, quid pro quo sexual favors or other unwanted verbal or physical sexual behaviors, sexual harassment is far from new in politics. Sexual harassment in politics knows

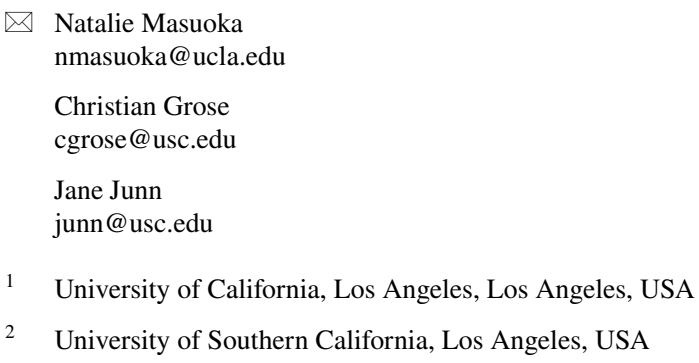


no party boundaries with elected officials from both parties having been accused of sexually harassing women. From 2000 to 2021, there were more than 20 formal investigations into members of Congress for sexual harassment or abuse. But the contours of this issue have changed in recent years due in particular to the more readily available video and audio recordings that undermine dismissals of "she said" with "he said." Furthermore, allegations of improper or illegal behavior are given new weight during a moment of \#MeToo and "Time's Up," movements which have generated public outrage and opposition to this behavior. These contemporary movements are built from decades of feminist activism. Allegations of sexual harassment against politicians have increasing negative resonance among some, but not all, voters.

Do allegations of sexual harassment against candidates affect voter support? If they do, then do all voters respond in the same way? Election outcomes have shown that voters are sometimes willing to elect politicians who have been accused of sexual harassment. ${ }^{1}$ One interpretation for this is that party overrides gender, ${ }^{2}$ where partisan loyalties are so strong that voters would rather support their party's candidate over the opposition party, even if their own party's candidate is accused of sexual harassment. Nevertheless, in dealing with an issue that highlights the unequal power relationship between men and women, partisanship is not the only factor to influence support of a candidate who has been accused of sexual harassment. While targets of sexual harassment can be of any gender, victims are usually female and perpetrators are usually male (Cortina \& Berdahl, 2008). Cognizant of these realities, it is reasonable to expect women voters to judge candidates for office more negatively on the basis of gendered issues like sexual harassment, compared to male voters (Herrnson et al., 2003; Paolino, 1995).

While one might expect a distinct role for party and for gender, we argue that emphasizing only party identification or only gender in order to identify one or the other as the driver of vote choice is too simplistic. We investigate reactions to sexual harassment, and hypothesize there to be systematic variation across partisan-gender

\footnotetext{
1 Politicians accused of harassment face varying levels of electoral punishment. In the U.S. House, some members have resigned in order to not face voters, and this includes Democrats and Republicans. For instance, Rep. Tom Reed (R-NY) was accused of harassment in 2021 by a former lobbyist, and opted not to run for reelection. Rep. Ruben Kihuen (D-NV) was accused of harassment in 2017, and opted not to seek reelection in 2018. Others, including Sen. Al Franken (D-MN), have also resigned their seats in Congress after allegations become public. These resignations imply there is an electoral cost to harassment allegations. Yet still others have survived elections after harassment allegations. Republican Donald Trump won an electoral college victory for president despite a tape of him bragging about sexual harassment released just prior to the 2016 election. Rep. Scott Desjarlais (R-TN), faced accusations that he had sex with his former patients (he was a doctor prior to winning a congressional seat in 2010), but has ultimately prevailed in multiple elections since this information was released. This variation in outcomes for legislators suggests voters electorally punish members of Congress differently.

2 Although we disaggregate our respondents into the category of "men" and "women," we use the term "gender" in this article rather than "sex." "Gender" references the social, cultural and political meanings attached to identities of people and their relationships with each other, rather than "sex" as a biological trait based on organs. Since this paper focuses on how self-identified respondents perceive and evaluate claims of sexual harassment of a candidate described as a man and targets described as women, gender is an appropriate term for this article.
} 
groups of Democratic women, Democratic men, Republican women and Republican men on the issue. Specifically, we expect that Democratic women and Republican men will take clear opposing views when evaluating candidates accused of harassment while the effect of sexual harassment allegations will be less obvious for Democratic men and Republican women. In short, the "treatment" of a sexual harassment allegation is received differently by partisan-gender groups and we expect these four groups to therefore occupy distinct positions in the evaluation of candidates.

By focusing on the issue of sexual harassment, our study offers further empirical evidence demonstrating how partisanship is gendered. While existing research shows men and masculinity associated with the Republican party; and women and femininity associated with the Democratic party (Bauer, 2019; Box-Steffensmeier et al., 2004; Hayes, 2011; Kaufman \& Petrocik, 1999; Winter, 2010), our study expands on the gendered dimensions of partisanship. Through sexual harassment, we emphasize the role of patriarchy in how it informs voter attitudes. As we will discuss below, voter sorting into partisan groups can be seen in the distinct differences between how Democrats and Republicans each think about traditional gender norms.

But attitudes on sexual harassment are not simply about norms. Since women are more likely to be a victim of sexual harassment than men, life experience and one's positionality resulting from their gender assignment inform responses to sexual harassment claims. Democratic women voters are primed both by their partisanship as well as their gender, the combined effect of which is stronger opposition to candidates accused of sexual harassment. In contrast, Republican men, similarly primed but in a distinct direction by their partisanship and their positionality as men, are systematically less punishing of candidates accused of violations. This is a topic where life experience and ideological beliefs about gender interact in important ways, and the issue of sexual harassment helps to further unearth the many gendered dimensions that are influenced heterogeneously by partisan ideology and partisan identity.

We begin with what scholars know about responses to sexual harassment and the roles of partisanship and gender in influencing voter behavior. We then develop hypotheses articulating expected differences across the four partisan-gender groups on the gendered issue of sexual harassment. We then present two tests of our argument with data collected from two randomized experiments. For external validity, we also present associational survey evidence from 2006 to 2018. In the two experiments and the correlational survey analysis, we find the most distinct patterns are exhibited by Democratic women, as they are most likely to electorally punish legislative candidates accused of harassment. These findings offer confirmation that there is an interaction between partisanship and gender on the issue of sexual harassment in influencing candidate evaluation and vote choice.

\section{Evaluations of Sexual Harassment in Politics and the Workplace}

Our study focuses on how candidate behaviors influence voter support. Political science research emphasizes desirable, reelection-seeking behaviors that leaders engage in to benefit constituents (Fenno, 1978; Yoshinaka \& Grose, 2008). There 
are fewer studies on undesirable candidate behaviors. These have tended to emphasize the effect of illegal financial decisions made by candidates and the impact on electoral outcomes or trust in government (e.g., Alford et al., 1994; Banducci \& Karp, 1994). Research shows that many incumbents remain in office even when voters learn of their illegal behavior (Basinger, 2012). This suggests that voters may still support their party's candidate when that candidate is found to have committed illegal actions.

Doherty et al. (2011) argue that the failure to explain why some leaders survive a scandal while others do not is partially due to the undertheorizing of how voters view candidate behaviors. They highlight a key overlooked dimension: whether or not the action involved is an abuse of power. The dominant practice has been to classify undesirable behaviors into categories of financial, sex, and other; this is too blunt of a measure because within each of these categories some behaviors involve an abuse of power while others do not. Doherty, Dowling and Miller argue that once greater precision to account for abuse of power is factored in, we are more likely to find voters willing to punish leaders, which implies that we can expect a reduced role for partisan loyalties. Consistent with this argument, sexual harassment is an abuse of power-especially when it involves a person in a leadership position such as a political candidate or elected official—and so represents a behavior that we would expect to dampen voter support.

Most of what we know about responses to sexual harassment is studied in the context of education and the workplace (but there is an emerging literature in political science; see Barnes et al., 2018; Cossette \& Craig, 2020; Costa et al., 2020; Craig $\&$ Cossette, 2020). The experience of sexual harassment is found to be widespread (Feldblum \& Lipnic, 2016; Hill \& Kearl, 2011) and there is significant variation in not only how individuals understand sexual harassment but also how they evaluate others who have committed sexual harassment. One important insight from these studies is that responses to sexual harassment are strongly influenced by one's gender: women are more likely to report being a victim (Fitzgerald et al., 1995, 1997) and are more likely to categorize a larger number of acts as harassment than men (Bursik, 1992; Bursik \& Gefter, 2011). Secondly, research shows that when there is a power difference between individuals, respondents are more likely to label an interaction as harassment (Bursik \& Gefter, 2011; Pina \& Gannon, 2012), and men are more likely than women to occupy leadership positions (Eagly \& Carli, 2018).

Further, respondents will often minimize the responsibility of the harasser (Jensen \& Gutek, 1982; Pina \& Gannon, 2012). Studies show that respondents use their evaluations of the victim in determining their views about harassment (Blumenthal, 1998; Prior \& Day, 1988). This offers some explanation for why official reporting rates of sexual harassment are lower than what actually occurs since victims are not always supported in making claims (Ridgeway \& Nakagawa, 2017). Since men are more likely to be the harasser and the one holding power, this reality shows how the gender hierarchy is central to dynamics of judgment where power differentials exist (Ridgeway, 2011). Status hierarchies incentivize the acceptance of power imbalance for those of low status and generate protections for those of high status thereby explaining why public response to sexual harassment is not automatically punitive toward men who commit harassment (Ridgeway \& Nakagawa, 2017). 
Even though women are more likely to be the victim, these expectations rooted in the power of patriarchal hierarchy mean some women may not automatically side with the victim and instead may hold sympathies for accused men (Manne, 2018).

Thus, we can expect that in politics, men and women will differ in their responses to sexual harassment at the ballot box. As more frequent targets of harassment and with different lived experiences, women will electorally punish candidates accused of harassment more than men will. At the same time, the relevance of status hierarchies leads us to also expect there to be variation in responses to harassment. It therefore cannot be assumed that voters of the same gender react homogeneously to a candidate accused of harassment, or that voters have the same levels of inclination to electorally punish.

\section{Role of Party: Group Loyalty and Ideological Sorting on Gender Attitudes}

Given that this is a study of vote choice, a key factor we must take into account is party identification. Because we focus on the issue of sexual harassment and scandal, the literature suggests that there are two different dimensions to party identification that we must account for: the ideological positions each party has taken on the issue of sexual harassment and the role of in-group loyalty.

First, in this contemporary era, the two parties have staked out two contrasting positions on their approach to traditional gender roles. Since the last realignment, Republicans have been the political party associated with conservatism and traditionalism (Layman, 2001) and hold a higher share of voters with higher incidences of authoritarian personality traits (Hetherington \& Weiler, 2009). Predispositions such as the embrace of traditional gender stereotypes and authoritarianism predict the likelihood of committing harassment; as well as attenuate negative responses to harassment (Cassese \& Holman, 2019; Fiske \& Glick, 1995; Pina \& Gannon, 2012). In contrast, voters affiliated with the Democratic party are, on balance, more favorable to feminist ideologies and gender equality messages which leads to greater opposition to gendered issues which involve a power difference between men and women (Castle et al., 2020; Conover, 1988; Cook \& Wilcox, 1991). Further, Democratic party activists express more positive attitudes toward feminism than GOP activists; and second-wave feminist movements have worked more closely with the Democratic party (Brown \& Lemi, 2020; Cooperman et al., 2021; Wolbrecht, 2000; Young, 2000).

Given these different ideological orientations toward gender roles, we expect that Democrats are more likely to view accusations of sexual harassment as significant social violations compared to Republicans. These important differences mean we can expect Republican voters to be less likely to respond negatively to harassment charges and therefore less likely to punish candidates accused of harassment relative to Democratic voters. Further, because acts of sexual harassment are more likely to violate belief systems for Democratic voters, we anticipate that the issue of sexual harassment may be more likely to motivate political action compared to Republicans and so we 
would find sexual harassment as an issue to influence Democratic vote choice compared to that of Republicans.

Second, the longstanding social psychological theories of motivated reasoning and confirmation bias predict greater allegiance to candidates associated with the groups with whom individuals profess loyalty (Lodge \& Taber, 2013). We therefore also expect partisan group loyalty to provide a systematic constraint for responses to allegations of sexual harassment. Given the wish to support one's political party, an in-party candidate who is accused of harassment will be evaluated quite differently compared to a candidate of the opposing party. In the case of evaluating a candidate from one's own party who has been accused of sexual harassment, voters must consider whether party overrides any negative reaction to the accusation. In contrast, learning that a candidate of the opposing party has committed harassment may amplify an already negative response to an out-party candidate. Research shows that out-party candidates accused of scandal receive lower evaluative ratings from voters than in-party candidates similarly accused of scandal (Grose \& Oppenheimer, 2007; Rothschild et al., 2021). Scholars point to partisan motivated reasoning for why voters will look more favorably toward in-party candidates (Leeper \& Slothuus, 2014), including those accused of sexual harassment (Costa et al., 2020).

Taken together, we expect there to be key differences between Democrats and Republicans in the relationship between partisanship and vote choice for candidates accused of harassment. For Democrats, ideological orientation could neutralize the role of party loyalty. The literature suggests that voters will be more critical of leaders who defy norms they embrace, which could dampen the effect of partisan loyalty (Lavine \& Gschwend, 2007). Given Democrats' ideological orientation to reject sexual harassment, they may be just as willing to criticize their own party leaders who are accused of engaging in such activity as they would opposite party leaders. In contrast, since we do not expect sexual harassment to be a politically mobilizing issue for Republicans, then the issue would not lead Republican voters to abandon their partisan group loyalties. As a result, Republican voters' partisan group loyalties leads them to overlook accusations of harassment waged on candidates of their own party while at the same time strengthening their negative assessments of candidates from the opposite party.

Our review of these two literatures on sexual harassment and partisanship allow us to generate separate expectations on the difference in responses between men and women and between Democrats and Republicans to sexual harassment. But as we demonstrate, these literatures are not frequently in direct conversation given that the issue of sexual harassment has been an understudied issue in political science. As we will argue below, through integrating these two literatures, we develop hypotheses which anticipate Democratic women voters to evaluate candidates accused of harassment differently relative to other party-gender groups.

\section{Partisanship is Gendered: Developing Empirical Expectations}

The objective of this article is to utilize the issue of sexual harassment to unearth the multiple dimensions in which partisanship is gendered. Political science has studied the associations between gender and political party. The longstanding literature on the gender gap has shown that women are significantly more likely to identify 
and vote for Democratic candidates compared to men (Kaufman \& Petrocik, 1999; Ondercin, 2017 but see Junn, 2017; Tien, 2017). Empirical studies demonstrate that the gender gap has persisted (Box-Steffensmeier et al., 2004) and can be found even when disaggregating by race (Bejarano, 2013) or other factors (Huddy et al., 2008). Research shows there are gendered traits associated with each political party (Hayes, 2011; Thomsen, 2014; Winter, 2010).

But there are other, more nuanced, ways that partisanship is gendered. By focusing on the issue of sexual harassment, we can explore how respondents weigh their ideological beliefs on gender roles against their perceptions of personal threat. First, in terms of ideological beliefs, responses to sexual harassment are informed by acceptance or denial of patriarchal relationships. As we discuss above, the acceptance or rejection of sexual harassment is a reflection of how individuals view the appropriateness of certain behaviors made by those in a power position. Given the longstanding and deeply institutionalized norms that uphold a status hierarchy which advantages men over women (Manne, 2018; Ridgeway, 2011), we can also say that reactions to sexual harassment reflect how individuals view the appropriate behavior of men and of women. Second, in terms of personal threat, those who perceive a very real threat or who personally experience harassment will respond in a different way from those who only understand harassment as an abstraction (e.g., Batson et al., 1996). There is a gendered dimension to personal experience since one's positionality living as a man results in a fundamentally different life experience from those who experience the world as a woman (Beauvoir, 1949; Klein, 1984). Victims of sexual harassment can be of any gender, but because women are more likely to occupy a less powerful position relative to men they are more likely to experience harassment or feel the threat of potential harassment in the future. This reality that harassment is a plausible personal threat to women, which will guide their responses to the issue of sexual harassment. Taken together, the issue of sexual harassment allows us to understand the interplay of these two gendered dimensions.

Empirically, we test the interplay of partisan belief system versus personal experience by considering the interactive effect of one's party identity and gender on responses to accusations of harassment. For this study, party identity as Republican or as Democrat is a proxy for belief system due to the partisan sorting on gender roles that has occurred. While theorists describe patriarchy as omnipresent to most contexts, there is clear partisan sorting in the U.S. (Levendusky, 2009; Wolbrecht, 2000). Those who are Republican more strongly embrace patriarchal values (Layman, 2001) such as traditional gender roles; while Democrats hold greater favorability towards feminism and gender equality (Castle et al., 2020; Conover, 1988; Cook $\&$ Wilcox, 1991). We then use the respondent's gender to account for the role of personal experience.

In the specific case of candidates accused of sexual harassment, we expect sexual harassment allegations will have larger effects on vote choice conditional on the interaction of voter gender and voter party. The result is distinctive responses across four partisan-gender groups of Democratic women, Democratic men, Republican women and Republican men. Existing studies confirm that within a political party, there are important political differences between women and men showing that gender continues to filter how individuals perceive and develop their politics (for 
example, see Barnes \& Cassese, 2017; Cassese, 2020; Cassese \& Holman, 2018; Schneider \& Bos, 2016). We expect the strongest negative evaluations towards a candidate who is accused of committing harassment from Democratic women. To gain empirical leverage on this, we compare how Democratic women evaluate a candidate from the same party against how they evaluate a candidate of the opposite party. We anticipate that Democratic women will electorally punish candidates whether they share the same party or not. For these voters, the intersection of their ideological orientations and gender leads them to connect their own life experiences as women with a political stance against tolerating gendered abuses of power. Therefore, we expect that when it comes to the issue of sexual harassment, Democratic women are not guided by party loyalty. On the opposite end of the spectrum, we expect Republican men will be the group least likely to punish a candidate accused of harassment. For these voters, their ideological orientation to accept traditional gender roles leads them to overlook instances of harassment; and they also are unlikely to have experiences as victims of harassment. We therefore expect partisan group loyalty to primarily drive evaluations of Republican men. Therefore, Republican men will negatively evaluate Democratic candidates and more positively evaluate Republican candidates even if those candidates are accused of engaging in sexual harassment.

Since gender and party offer opposing ideological cues on sexual harassment for Democratic men and Republican women, we expect their evaluations of a candidate accused of committing harassment to fall between those of Democratic women and Republican men (see also Cassese and Barnes 2018). For Democratic men, they hold an ideological orientation consistent with their party in support of gender equality but at the same time as men they are less likely to have experienced being a target of sexual harassment. For Republican women, they are more likely to have been targeted for sexual harassment by virtue of their sex, but their ideological position on traditional gender roles leads them to hold weaker opposition to practices of harassment. In fact, women who embrace traditional gender roles are more likely to blame themselves (and not the male perpetrator) if they personally experience sexual harassment (Jensen \& Gutek, 1982). Democratic men and Republican women both hold a gender identity that conflicts with their ideological orientation making it more difficult to offer a consistent assessment of a candidate accused of harassment. Because of these conflicting influences, we anticipate that the issue of sexual harassment may not be an issue that leads these voters to overlook the value of partisan loyalty. We therefore expect that both Democratic men and Republican women will evaluate candidates of the same party more positively than candidates of the opposite party even in the case when accusations of sexual harassment have been known.

Our expectations are guided by both theory and a review of the literature, but we also empirically confirmed that each of the four partisan-gender groups hold distinctive positions on traditional gender roles. Existing studies have already shown that hostile sexism - which underpins the belief that gender equality is a threat (Fiske \& Glick, 1995) - is associated with stronger GOP support (Cassese \& Holman, 2019; Valentino et al., 2018). In an analysis of our original survey data, we confirm that overall, Republicans are more supportive of traditional roles for women and have higher levels of hostile sexism (see Fiske \& Glick, 1995) compared to Democrats. 
Within party, men are higher on traditional gender roles and hostile sexism compared to women, with Democratic women voters evincing the lowest support for traditional women's roles and hostile sexism. On a battery of traditional roles questions, ${ }^{3}$ Democratic women answer with the most muted embrace of patriarchal support with the lowest mean score (4.1 on a scale of 13) compared to Democratic men (5.3), Republican women (6.8), and Republican men (6.0) (see Online Appendix A/ Table A1). Variation across gender-party group was similar on the hostile sexism battery collected in the 2016 American National Election Study (ANES). In our analysis of the ANES, the mean hostile sexism score was the lowest for Democratic women ( 0.88 on a scale of 3$)$, followed by Democratic men (1.26) and Republican women (1.23), and finally the highest average score was for Republican men (1.42). ${ }^{4}$ These empirical results further confirm our argument that the distribution of ideological beliefs and personal experiences are reflected in the patterns found across the four partisan-gender groups and that we should expect an interactive effect of party and gender on responses to accusations of sexual harassment.

\section{Experimental Study 1: The Effect of Candidate Harassment Allegations on Voters}

To test our expectations, we conduct a survey experiment where respondents evaluate a political candidate running for U.S. Congress. ${ }^{5}$ This national internet-based survey had a sample of 2,036 U.S. adults who identify as either Democrat or Republican. ${ }^{6}$ The experiment was block randomized into the four party-gender social groups of theoretical interest: Democratic women $(n=505)$, Republican women $(n=507)$, Democratic men $(n=513)$, and Republican men $(n=511)$. Because of the randomization, all other confounding variables that may explain vote choice beyond our randomized conditions are "controlled for" in expectation through the experimental design. This block randomization is important given our expectations that there will be heterogeneous treatment effects, which theorizes differences between groups in response to the same treatment. It requires the implementation of a design methodology that requires both a priori theorizing and, empirically, more resources

\footnotetext{
3 The items on the battery were agreement with the following: (1) A preschool child is likely to suffer if his or her mother work; (2) A job is alright but what most women really want is a home and children; (3) A husband's job is to earn money; a wife's job is to look after the home and family".

4 The 2016 ANES asked respondents if they supported the following statements: "Women fail to appreciate what men do for them" (V161508); "Women seek to gain power by getting control over men" (V101509) and "Women put men on a tight leash" (V161510). We combined responses to these items into an index variable on a scale of $0-3$. For party identity we use the variable V161158x and exclude independent leaners from those classified as Democrats and Republicans. The post-survey weight (V16002) was used to calculate these means.

${ }^{5}$ Replication data for this study is available at: https://dataverse.harvard.edu/dataset.xhtml?persistentId= doi:10.7910/DVN/BUYCLX

6 A sample of 3,050 adults was collected with an online Qualtrics sample in December 2018. Given our research question, this study analyzes only the 2036 who identified as either Republican or Democrat.
} 
in degrees of freedom (Ratkovic, 2021). We pre-registered our analysis plan, specifying the differential treatment effects expected by partisan-gender groups.

All subjects in the study were first told that they would be evaluating a candidate for the U.S. Congress and were provided a short personal biography (see Online Appendix A). ${ }^{7}$ Then, respondents in each of the four party-gender groups were randomly assigned to a candidate who was identified as either a Democrat or a Republican. ${ }^{8}$ All other information provided in the biography was identical across conditions, including the candidate's name, indicating a candidate who identifies as male. Randomizing the party of the candidate was necessary in the design in order to compare whether and the extent to which voters in each of the party-gender groups assessed the candidate differently on the basis of his party identification, with the expectation being that voters would judge co-partisans with more leniency due to motivated reasoning and confirmation bias.

After reading about the candidate with the only difference being the randomly assigned party of the candidate, the primary randomization of interest was included. Within each block of the four party-gender groups, respondents were randomly assigned to three different conditions: a treatment of a breaking news story which described sexual harassment allegations about the candidate (which we label the harassment treatment group); a breaking news story which described a mild, nongendered violation unrelated to harassment committed by the candidate (which we label the placebo condition); or a control group in which no additional information about the candidate was provided. ${ }^{9}$

The harassment treatment group read an article reporting the following information: "Candidate Matt Franklin is facing allegations of sexual misconduct, including sexually harassing 3 female staff workers in his office at the capitol, and 2 women campaign workers for which there is photographic evidence. During the course of Franklin's campaign in the state primary for the nomination, Franklin allegedly made inappropriate remarks and groped the women workers in his office." See Online Appendix A for full wording of treatment and survey instrument. The placebo condition introduced a scandal violation, but one that has no gendered undertones. In the text that follows, we present only the results of the treatment condition relative to the control condition (where no information was given to voters), but refer the reader to the Online Appendix for the placebo results. ${ }^{10}$ After being exposed to

\footnotetext{
7 In this study, we focus on male candidates who have been accused of harassment and thus candidate gender is fixed. However, Cossette and Craig (2020) include a scenario in which the politician accused of sexual harassment is a woman.

${ }^{8}$ The experiment also included a "no party" condition where candidate party is not disclosed to respondents. Given our hypotheses related to partisanship, we excluded the analysis of the "no party" candidate in the text but provide results for this condition in Appendix B.

${ }^{9}$ For sample sizes and balance checks of the $2 \times 3$ experiment, see Appendix B/Tables B1 and B2.

10 The placebo condition was designed to account for the possibility that the introduction of any negative information about a candidate could depress the likelihood of voting for him. The placebo news story on traffic violations was designed to mimic the sexual harassment condition in terms of the frequency of the incidents and the documentation of the infractions but was selected as a violation without any gendered undertones. We expected the placebo condition to negatively influence candidate evaluations but in contrast to the sexual harassment treatment condition, the placebo condition should work homogeneously
} 
the treatment, respondents were asked to evaluate the candidate. Our primary outcome variable is Vote likelihood. Respondents were asked, post-treatment, "How likely are you to vote for" the candidate for Congress ( $1=$ very unlikely; $5=$ very likely). ${ }^{11}$

\section{Experimental Study 1 Results: Heterogeneous Effects by Party and Gender}

To evaluate voter responses to candidates accused of harassment, we first focus on comparisons between the harassment treatment and control condition while randomly varying the party of the candidate. Figure 1 reports these results, which does not consider voter gender or voter party. Thus, we are showing just the average-treatment effect within the condition of a Democratic candidate or within the condition of a Republican candidate, as might be done in a study that does not consider voter group-level heterogenous effects. In Fig. 1, we see that the mean for the harassment treatment is lower than the control mean regardless of the party of the candidate. The difference between the control and harassment treatment $(-1.32)$ is significant when the candidate is a Democrat $(p \leq 0.05)$ (see also table of these difference-ofmean results in Online Appendix B/Table B3). ${ }^{12}$ There are also significant differences on the harassment condition when respondents are told the candidate is a Republican $(-1.13$ difference; $p \leq 0.05)$. This shows that an empirical strategy which did not consider voter-group heterogenous effects yielded a conclusion that all voters electorally punish harassing candidates at similar magnitudes. ${ }^{13}$

We test our empirical expectations by reporting the mean post-treatment likelihood to vote for the candidate across the harassment and control conditions while also disaggregating by the four party-gender voter groups. In Fig. 2, the treatment conditions are displayed with a square and the control conditions are indicated with a circle (see also table of difference-of-means results in Online Appendix B/ Table B4a). Among the four party-gender groups, all respondents in the harassment treatment condition are less likely to vote for the candidate than in the control condition in which no additional information about the candidate was provided. For all four party-gender groups, the differences between treatment and control conditions

\footnotetext{
Footnote 10 (continued)

across men and women because the nature of the violation is not gendered. See Appendix B for these placebo results.

11 To ensure reliability of our results, we also considered a second outcome variable, a Feeling thermometer of the candidate (which ranges from 0 to 100). We find the same patterns for both outcome variables. See Appendix B for analysis on the feeling thermometer variable.

${ }^{12}$ In this section, we calculate all differences across treatment groups using ANOVA with Tukey HSD test, and this test allows for conservative estimates of statistical significance given multiple tests.

${ }^{13}$ In our analysis of the "no party" candidate condition, we find that the difference between the harassment treatment and control is -1.33 (significant at $p<0.05$ ) and is similar to the evaluations of the Democratic candidate. So even when including the "no party" candidate condition, we find that the Republican candidate is penalized slightly less relative to the other candidates. See Appendix B/Table B3 for results.
} 
are statistically significant $(p \leq 0.05)$. Overall, this shows that all party-gender groups punish a candidate accused of sexual harassment.

Consistent with expectations, the magnitude by which voters punish the candidate varies across the four party-gender groups. In the control condition, each partisangender group is fairly similar in their mean vote likelihood, with all groups above 3 (where 3 indicates being neither likely nor unlikely to vote for the candidate). When comparing the control condition to the treatment condition, results confirm our hypotheses that Democratic women will more seriously punish candidates alleged to have sexually harassed women. Democratic women's evaluations of the candidate accused of harassment (mean 1.82) are lower than those of Republican men's evaluations (mean 2.40). The difference between the treatment and control groups is also largest for Democratic women with a difference of -1.63 points on the 5-point scale. In contrast, for Republican men, the difference between the control and treatment conditions is only -0.93 points. The difference-in-difference in reported likelihood to vote for the candidate between Democratic women and Republican men who have received the treatment condition is the largest in magnitude across all party-gender groups and is statistically significant $(p \leq 0.01)$.

Democratic women are also distinct from Republican women and Democratic men. The difference-in-difference estimate between Democratic women and Democratic men is - 0.36; and for Democratic women and Republican women is -0.40 . Both of these comparisons are statistically significant, showing that Democratic women punish the candidate accused of sexual harassment more harshly than the other three party-gender groups. This also shows important gender differences within Democratic voters. Intriguingly, we also find that Democratic men are more likely to punish the candidate accused of harassment than Republican men, demonstrating partisan distinctions within men. In this instance, gender alone is not sufficient for understanding the impact of sexual harassment allegations on voter support-as partisanship separates men's willingness to support the harassing candidate. At the same time, we do not find Republican women to differ significantly from Republican men or Democratic men. Comparing all these difference-in-difference estimates, Republican women and Democratic men offer similar responses to the candidate accused of sexual harassment with the difference-in-difference estimate small in magnitude $(-0.04)$ and statistically insignificant. Moreover, while the magnitude of difference between Republican women and Republican men is relatively sizeable $(-0.30)$, results show this difference-in-difference is not quite statistically significant.

We also calculate effect sizes to further verify these results. The effect sizes when comparing Democratic women to the other three party-gender groups on the harassment are moderate. When comparing Democratic women with Republican men the effect size is the largest at $d=0.44$ while it is $d=0.28$ when compared against Republican women and $d=0.34$ when compared to Democratic men. Consistent with the difference of means analyses, we find that the effect sizes are small when making comparisons across the other three groups. This analysis of effect sizes 

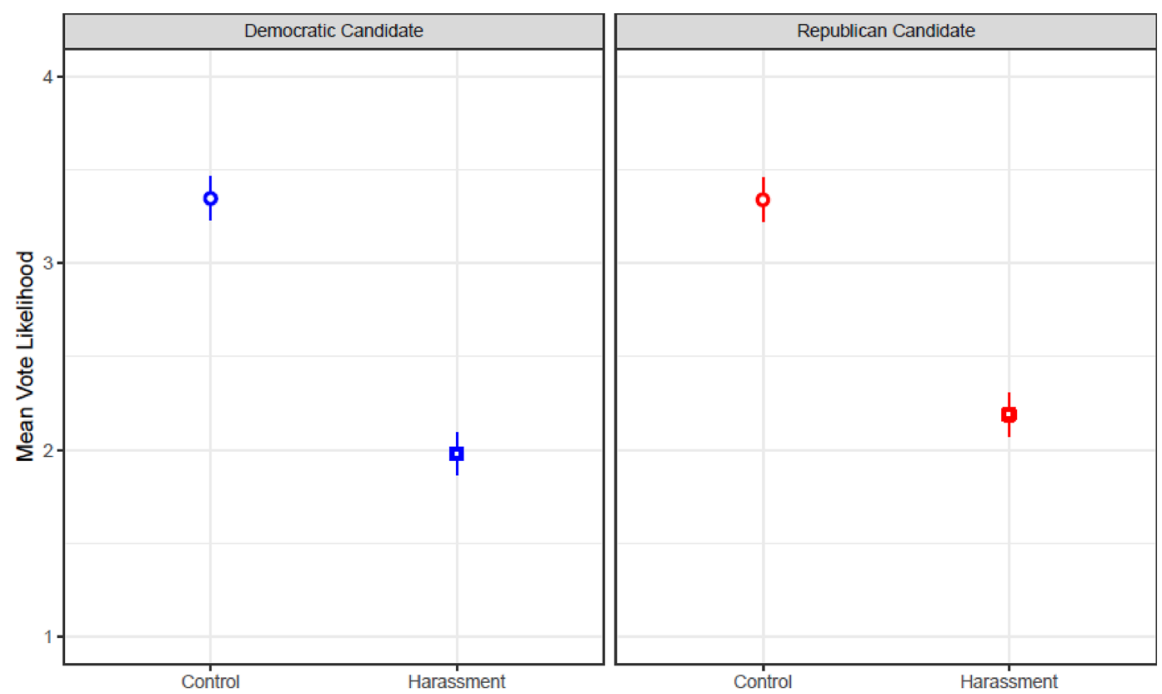

Fig. 1 Visualizing the effect of the harassment treatment on vote likelihood, by candidate party in experiment 1

confirm that Democratic women are the most responsive to the issue of harassment relative to the other three party-gender groups. ${ }^{14}$

Beyond responses to harassment, we also hypothesized that party loyalty will attenuate negative evaluations toward the candidate if that candidate is of the same party as the respondent. The lower half in Fig. 3 compares the mean vote likelihood of the sexual harassment treatment and control group when respondents share the same party as the candidate (see also full table of means in Online Appendix B/Tables B6 and B7a). Republican men assign the highest mean vote likelihood rating to the Republican candidate accused of harassment (2.81), which is nearly an entire point higher compared to the mean vote likelihood made by Democratic women to the Democratic candidate accused of harassment (1.87); and almost halfa-point higher than the vote likelihood made by Republican women to the Republican candidate accused of harassment (2.40). Difference-in-difference tests confirm that Democratic women assign the harshest punishment relative to the other three party-gender groups. The difference-in-difference estimate between the same-party harassment treatment and control group condition for Democratic women is significantly larger than those estimates for the other three party-gender groups. All other difference-in-difference estimates between Democratic men, Republican women, and Republican men are insignificant. This tells us that while Republican men and women and Democratic men punish a shared-party candidate who has been accused of harassment, Democratic women punish their own party's candidate much more

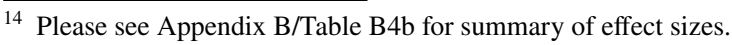



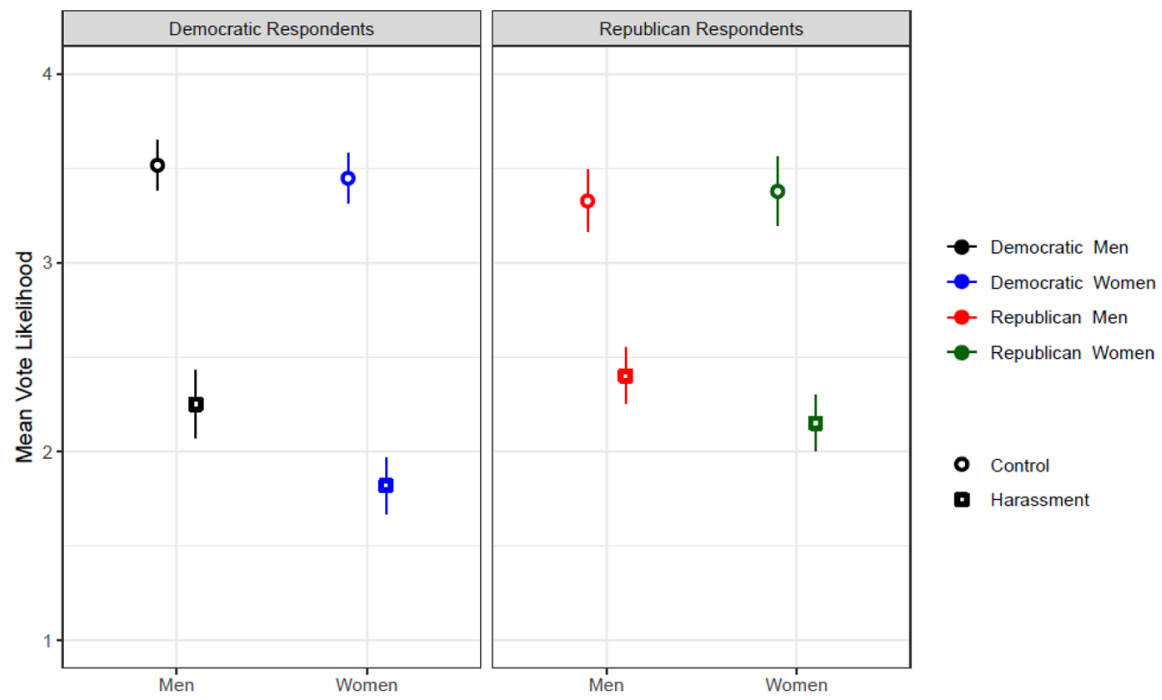

Fig. 2 Visualizing the effect of the harassment treatment on vote likelihood, by voter party-gender group in experiment 1

severely compared to these three other groups. Democratic women are a distinctive partisan-gender group.

The top cells in Fig. 3 present the mean vote likelihood ratings when respondents are told the candidate is of the opposite party (see also table of means in Online Appendix B/Table B7a). We continue to find that accusations of harassment dampen support for an opposite-party candidate relative to the control for all four groups. But consistent with our expectations, there is a smaller difference in vote likelihood between the opposite-party candidate accused of harassment and the control relative to what we found for candidates of the same party. Respondents are generally less supportive of a candidate of the opposite party (as evidenced in the ratings for the opposite-party candidate in the control condition relative to the ratings for the same-party candidate in the control condition). ${ }^{15}$ Thus, the added information that the opposing-party candidate is accused of harassment seems to further solidify their unwillingness to support that candidate whereas evaluations of candidates of the same party decline by a larger magnitude.

Even among the evaluations of the opposite-party candidate we also find variation in the difference-of-means results across the four party-gender groups. The difference of means shows that Democratic women, Democratic men, and Republican women punish the opposite-party candidate accused of harassment relative to the opposite-party candidate control condition. In contrast, we find there is no

\footnotetext{
${ }^{15}$ We compared vote likelihood between the same-party control group and opposing-party control group and found that for all party-gender groups, the same-party candidate in the control group received higher ratings compared to the opposing party in the control group (see Appendix B/Tables B6 and B7a).
} 


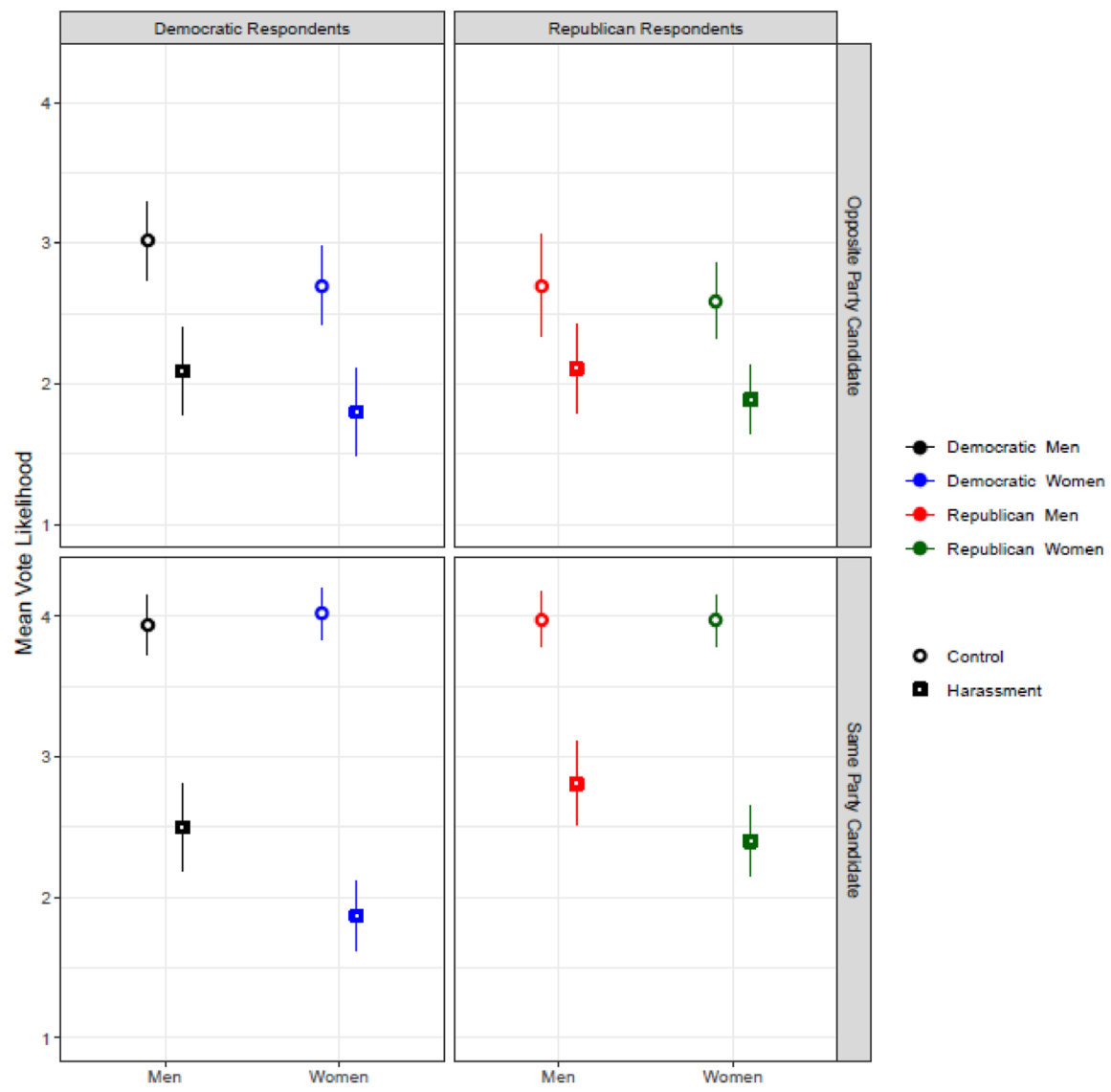

Fig. 3 Effect of harassment treatment versus control condition by party-gender group in experiment 1, opposite-party and same-party candidates

statistically significant difference in Republican men's evaluations of the opposite-party candidate in the harassment treatment relative to the control condition. Therefore, Republican men's low assessments of the opposite-party candidate are unmoved by the additional information that the opposite-party candidate has been accused of harassment. ${ }^{16}$

\footnotetext{
${ }^{16}$ We also asked respondents a pre-treatment vote likelihood question prior to being exposed an experimental condition. The respondents first viewed the candidate biography in Appendix A and then were asked the five-point vote likelihood question. Respondents then were randomly assigned to an experimental condition and then post-treatment were asked the exact same vote likelihood question. Only this latter post-treatment measure is reported in the main text for ease of interpretation. However, for robustness and to provide more precision in statistical estimates, in Appendix B (Tables B8 and B9) we examine another outcome variable that is the difference between these two measures (post-treatment vote likelihood minus pre-treatment vote likelihood) for all respondents. Results are similar to those in the text relying upon just the post-treatment vote likelihood measure.
} 
Comparing results between evaluations of same and opposite party candidates, we find that accusations of sexual harassment influence Democratic women the most and Republican men the least. ${ }^{17}$ Moreover, we find that Republican men are generally less moved by accusations of harassment even when considering the partisanship of the candidate. Republican men assign a higher mean vote likelihood score to the opposite-party candidate accused of harassment (2.11) compared to Democratic women's mean vote likelihood ratings of their own party's candidate accused of harassment (1.87). ${ }^{18}$ We further confirm these differences across groups by calculating effect sizes by treatment group across the four party-gender groups. ${ }^{19}$ The magnitude of effect sizes mirror similar relationships found in the differencein-difference results we report in the main text. Most significantly, we find an effect size of $d=0.18$ in the difference between Republican men and Democratic women in evaluation of the Democratic candidate in contrast to an effect size of $d=0.77$ in their evaluation of the Republican candidate. Taken together, the results of our experiment conform to our expectations on the differences across the four party-gender groups. ${ }^{20}$

Finally, as described above, we also analyzed the placebo condition (a non-gendered accusation) relative to the control and harassment conditions. We find that party-gender groups vary in their response to the harassment condition consistent with our expectations but the same pattern does not hold for the placebo condition, which had no gendered component to the violation. The results from the placebo thus further uphold our expectations that the interactive effect of party-gender is specific to the gendered issue of sexual harassment. Party-gender groups do not vary in the same way for all issues and there is an important distinction between gendered and non-gendered issues. See Online Appendix B (Tables B15, B16, and B17) for analysis of the placebo.

\footnotetext{
${ }^{17}$ We found differences in evaluation of the no-party candidate across the four party-gender groups. Looking at the control group, Democratic women and men and Republican women were significantly more likely to vote for a no-party candidate compared to the opposite-party candidate. In contrast, Republican men were more likely to vote for the same-party candidate relative to the no-party candidate. When we analyzed the harassment treatment, we did not find any significant differences in mean vote likelihoods of the non-partisan candidate relative to the shared party or opposite-party candidate for all four party-gender groups (see Appendix B/Table B11 and Table B12).

18 We also compared vote-likelihood ratings between the same-party harassment treatment and opposing-party harassment treatment across the four party-gender groups and found that while the difference in means across the two conditions was not statistically significant for any of the groups, the difference-indifference estimates between Republicans (of either gender) and Democrats (of either gender) are statistically significant. Comparing across only those who received the harassment treatment, we find Republican voters of either gender are less punitive towards the same-party candidate than the opposing-party candidate compared with Democratic voters (see Appendix B/Table B10).

${ }^{19}$ See Appendix B/Table $7 \mathrm{~b}$ for summary of effect sizes.

${ }^{20}$ As mentioned earlier, results using feeling thermometer as the dependent variable are in Appendix B/ Tables B13 and B14.
} 


\section{Experimental Study 2: Replication Demonstrates Heterogeneous Treatment Effects}

In addition to the first study, we conducted a second experiment that is a replication on a different sample of respondents. ${ }^{21}$ Almost all components of the study were the same. ${ }^{22}$ The results again confirm that Democratic women most severely punish same-party candidates who are accused of harassment relative to the other three party-gender groups. But in contrast to what we find in experiment 1 , we find statistically significant variation between Republican men and all other party-gender groups. Republican men are significantly less likely to punish same-party candidates relative to both Democratic men and Republican women. In addition, experiment 1 found that there is more of a partisan difference in how respondents evaluate an opposing-party candidate, and experiment 2 shows greater variation across the four party-gender groups. However, while we find some differences between the two experiments, the results continue to conform with our expectations. Please see Online Appendix C for information on the sample and replication. Online Appendix $\mathrm{C}$ includes all results for study 2 paralleling those results presented in study 1 earlier.

\section{Study 3: Individual Attitudes About Incumbents Accused of Harassment, 2006-2018}

The experiment and the replication demonstrate that party-gender groups have distinct and heterogenous responses to allegations of harassment against political elites, and suggest that Democratic women respond most negatively to harassment regardless of the political party of the elected official. To assess the external validity of these experimental findings, we also examine observational data from 2006 to 2018. We use CCES data from this period to analyze individual-level approval of U.S. House representatives. For this analysis, we are unable to analyze respondent vote choice as most accused members resign or retire. However, a number of House members have been accused of sexual harassment against women during the 2006 to 2018 period, and thus we can assess if these accusations influence respondents' approval ratings. While associational, these CCES analyses provide important generalizability to the causal findings presented above in the analysis of the two experiments.

\footnotetext{
21 This sample $(n=2093)$ was collected via Mechanical Turk. Respondents were in the U.S. only and were paid $\$ 1.25$. Initial screening questions were placed in this survey to ensure respondents were human. One question asked respondents to transcribe handwritten text and a second was a manipulation check asking respondents about the text of treatment vignettes in order to monitor whether respondents paid attention (though to avoid post-treatment bias, all these respondents are included).

22 The main difference was that in experiment 2 , simple randomization was conducted, instead of block randomization as in experiment 1 .
} 
We separately analyze OLS models ${ }^{23}$ for our four voter subgroups: Democratic women, Democratic men, Republican women, and Republican men for same-party House incumbents and opposing-party House incumbents. The cumulative CCES file includes 2625 voters who lived in a congressional district in which their representative was accused of and investigated for sexual harassment between 2006 and 2018. If our experimental findings translate to voter ratings of actual House incumbents, then we should observe that Democratic women rate House members accused of harassment lower than those not accused for both same-party and opposing-party incumbents. In contrast, we anticipate that other party-gender groups may not rate same-party House members accused of harassment lower than those not accused of harassment. Given our argument, Democratic women will be distinctive and express the most negative attitudes toward both same-party and out-party incumbents accused of harassment.

The respondent from the CCES cumulative file is the unit of analysis. The dependent variable is approval of U.S. House representative, coded on a 4-point scale with the highest value indicating the respondent chose "strongly approve" and the lowest value indicating "strongly disapprove." Like the experimental results, we separately analyze the four party-gender respondent groups when the House incumbent shares the party of the respondent; and when the House incumbent is of the opposing party. ${ }^{24}$

The key independent variable, sexual harassment by incumbent, indicates whether the incumbent was accused of harassment $(1=$ yes; $0=$ no). The data are from the U.S. Congressional Ethics Committee, as collected by govtrack.us. This variable is coded 1 if the CCES respondent took the survey on a date after the House incumbent was accused of harassment against a woman; and 0 if they took the survey before the accusation; or 0 if the incumbent was never accused of harassment. We take into account the date of the survey as harassment allegations are sometimes publicly revealed during an election cycle concurrent with the CCES's fielding. Other independent variables are included for education, age, race, ideology, income and retrospective economic evaluations.

In Tables 1 and 2, we report the results for only our key independent variable. ${ }^{25}$ Table 1 shows results when the respondent and incumbent share the same party. With same-party incumbents, sexual harassment allegations are associated with lower approval ratings only among Democratic women voters. Democratic men, Republican women, and Republican men did not rate incumbents accused of harassment any lower than those not accused of harassment when they shared the legislator's party. Table 2 shows that harassment allegations reduce support for House

\footnotetext{
${ }^{23}$ For ease of interpretation, we provide OLS coefficients in the main text. The approval rating is measured using a four-point ordinal scale. In Appendix D, we present results with ordered logit models.

24 We used the 3-point party identification question in CCES and the party of the House incumbent to construct whether the incumbent was of the same or opposing party of the respondent. We only examine respondents who identify as Democrat or Republican; and only examine respondents represented by major-party House incumbents.

25 See Appendix D where we describe the measures of these other independent variables and present the results for the full regression model.
} 
incumbents of the opposing party to the voter. Among all four party-gender groups, harassment allegations are associated with lower approval ratings for opposite-party incumbents.

Democratic women voters always rate House incumbents who have been accused of harassment lower-regardless of whether they share the same party or are from the opposing party. This is consistent with our experimental findings, which showed Democratic women were the only party-gender group that regularly electorally punished candidates accused of sexual harassment regardless of candidate party.

\section{Conclusion}

This research on sexual harassment and candidate evaluation was designed to develop expectations and empirically test which groups of voters punish politicians for this abuse of power. The results from both experiments and the associational data provide strong support that, in particular, Democratic women are the group that consistently punishes candidates who have been accused of harassment, even when they represent the shared party. The empirical study demonstrates the distinctive finding for Democratic women, but our conceptual development identifying the unique dimensions of ideological beliefs about gender and personal experience embedded in the issue of sexual harassment furthermore offers an explanation for why Democratic women consistently reject candidates who are accused of sexual harassment even when that candidate shares the same party. For Democratic women, candidates accused of sexual harassment activate both dimensions of ideological beliefs and personal experience making this a salient issue influencing their vote choice. So in the context of a sexual harassment claim for Democratic women, beliefs and personal experience diminish the strong role of shared party that typically predicts candidate support. Given that women make up a majority share of the Democratic voters (Junn \& Masuoka, 2020), the consequences of sexual harassment incidents may be particularly threatening to Democratic (men) elected officials.

Similarly, by emphasizing the two dimensions of ideological beliefs and personal experience, we can understand why the effects for the other three partisan groups are not consistent. We expected there to be competing concerns for Republican women and Democratic men and, in that way, it is unsurprising that there were not consistent results for these two groups in our studies. For both Democratic men and Republican women, the contrast between their ideological beliefs and their personal experience in many ways neutralize one another on the issue of sexual harassment. But we emphasize that the reasons for this are different for each group. Democratic men hold relatively greater support for gender equity but there is less real threat of experiencing sexual harassment, making the issue important but perhaps not politically mobilizing. In contrast, Republican women hold a conflict between their embrace of traditional gender roles and the real threat they face being victims of harassment. Like Democratic men, this conflict results in a varied response to accusations of harassment. Interestingly, while we expected there to be significant results for Republican men across studies, we 
Table 1 Harassment allegations and approval, CCES respondent has same party as house incumbent

Dep. variable: Approval rating of U.S. House representative (higher values = higher approval)

\begin{tabular}{llll}
\hline $\begin{array}{l}\text { Democratic women } \\
\text { respondents }\end{array}$ & $\begin{array}{l}\text { Democratic men } \\
\text { respondents }\end{array}$ & $\begin{array}{l}\text { Republican women } \\
\text { respondents }\end{array}$ & $\begin{array}{l}\text { Republican } \\
\text { men respond- } \\
\text { ents }\end{array}$ \\
\hline$-0.25(0.10)^{*}$ & $0.05(0.14)$ & $-0.14(0.22)$ & $0.07(0.11)$ \\
$3.16(0.04)^{*}$ & $3.39(0.05)^{*}$ & $2.16(0.05)^{*}$ & $2.00(0.06)^{*}$ \\
36,678 & 27,080 & 26,800 & 29,408
\end{tabular}

The unit of analysis is the individual CCES respondent. Other independent variables are included but not displayed (ideology, age, education, income, white, economic retrospections, year dummies). Cells present OLS coefficients with standard errors in parentheses. For full model results, see Online Appendix D $* \mathrm{p}<0.05$

Table 2 Harassment allegations and approval, CCES respondent has opposite party than house incumbent

\begin{tabular}{|c|c|c|c|c|}
\hline & \multicolumn{4}{|c|}{$\begin{array}{l}\text { Dep. variable: Approval rating of U.S. House representative (higher values }=\text { higher } \\
\text { approval) }\end{array}$} \\
\hline & $\begin{array}{l}\text { Democratic } \\
\text { women respond- } \\
\text { ents }\end{array}$ & $\begin{array}{l}\text { Democratic } \\
\text { men respond- } \\
\text { ents }\end{array}$ & $\begin{array}{l}\text { Republican } \\
\text { women respond- } \\
\text { ents }\end{array}$ & Republican men respondents \\
\hline $\begin{array}{l}\text { Sexual harass- } \\
\text { ment by } \\
\text { incumbent }\end{array}$ & $-0.39(0.27)^{*}$ & $-0.33(0.24)^{*}$ & $-0.22(0.15)^{*}$ & $-0.22(0.10)^{* *}$ \\
\hline Constant & $1.99(0.05)^{* *}$ & $2.05(0.07)^{* *}$ & $3.99(0.07)^{* *}$ & $3.98(0.07)^{* *}$ \\
\hline $\mathrm{N}$ & 30,134 & 21,016 & 13,372 & 17,424 \\
\hline
\end{tabular}

The unit of analysis is the individual CCES respondent. Other independent variables are included but not displayed (ideology, age, education, income, white, economic retrospection, year dummies). Cells present OLS coefficients with standard errors in parentheses. For full results, see Online Appendix D

$* * \mathrm{p}<0.05 ; * \mathrm{p}<0.10$

did not find this to be consistently the case. Although ideological beliefs and personal experience are in alignment for Republican men, perhaps since the issue of sexual harassment does not conflict with their beliefs or personal experience, their responses to a candidate who has been accused of sexual harassment are no different from a candidate who has not been accused of such behavior.

This research also suggests there are particular gendered issues where there is abuse of power that is most likely to trigger the interplay of gender and party in voter evaluations. This relationship between party and identity may emerge in other domains. Future researchers should consider other instances in which voter demographic positionality interacts with the parties' issue positions to affect voter evaluations. Additional research should also probe how these differences, especially between Democratic and Republican women, manifest themselves in legislative election outcomes and in micro-level attitudes. 
Some might summarize the results presented here as further confirmation with the existing literature that partisanship has a stronger role over gender (for example Dolan, 2014; Klar, 2018). While it is indeed the case that there is a distinctive difference between Democrats and Republicans on the issue of sexual harassment, we caution against the typical strategy employed in political behavior to focus on the overall average effect of one particular factor. Once disaggregating by the four partygender groups, we observe important gender variation within party. On the issue of sexual harassment presented here, we find a gender effect specifically among Democrats. It is this distinctive interactive effect of partisanship and gender triggered by a specific issue that is under-emphasized in the literature. Yet, with increased focus on micro-targeting of specific subpopulations that is now occurring in campaigns today, identifying subtle but distinctive policy preferences found to exist in detailed subpopulations will become a more common practice that could have electoral consequences.

Supplementary Information The online version contains supplementary material available at https://doi. org/10.1007/s11109-021-09761-3.

Acknowledgements We thank Nico Napolio for research assistance. This paper was presented at 2018 APSA Annual Meeting, 2019 Racial and Ethnic Politics Conference at UC Irvine and the 2020 Southern California Political Behavior Conference at UCLA. An earlier version was presented at Princeton University in 2018.

Open Access This article is licensed under a Creative Commons Attribution 4.0 International License, which permits use, sharing, adaptation, distribution and reproduction in any medium or format, as long as you give appropriate credit to the original author(s) and the source, provide a link to the Creative Commons licence, and indicate if changes were made. The images or other third party material in this article are included in the article's Creative Commons licence, unless indicated otherwise in a credit line to the material. If material is not included in the article's Creative Commons licence and your intended use is not permitted by statutory regulation or exceeds the permitted use, you will need to obtain permission directly from the copyright holder. To view a copy of this licence, visit http://creativecommons.org/licen ses/by/4.0\%.

\section{$\underline{\text { References }}$}

Alford, J., Teeters, H., Ward, D. S., \& Wilson, R. K. (1994). Overdraft: The political cost of congressional malfeasance. Journal of Politics, 56, 788-801.

Banducci, S., \& Karp, J. (1994). Electoral Consequences of Scandal and Reapportionment in the 1992 House Elections. American Politics Quarterly, 22, 3-26.

Barnes, T. D., Beaulieu, E., \& Saxton, G. W. (2018). Sex and corruption: How sexism shapes voters' responses to scandal. Politics, Groups, and Identities.

Barnes, T., \& Cassese, E. (2017). American Party Women: A look at the gender gap within parties. Political Research Quarterly, 70, 127-141.

Basinger, S. (2012). Scandals and congressional elections in the post-watergate era. Political Research Quarterly, 66, 385-398.

Batson, C. D., Sympson, S., Hindman, J., Peter Decruz, R., Todd, M., Weeks, J., Jennings, G., \& Burns, C. (1996). I've been there, too: Effect on empathy of prior experience with a need. Personality and Social Psychology Bulletin, 22, 474-482. 
Bauer, N. (2019). The effects of partisan trespassing strategies across candidate sex. Political Behavior, 41, 897-915.

Bejarano, C. (2013). The Latino Gender Gap in U.S. Politics. Routledge.

Blumenthal, J. (1998). The reasonable woman standard. Law and Human Behavior, 22, 33-57.

Box-Steffensmeier, J., DeBoef, S., \& Lin, T.-M. (2004). The dynamics of the partisan gender gap. American Political Science Review, 98, 515-528.

Brown, N., \& Lemi, D. (2020). Life for me ain't been no crystal stair. Boston University Law Review, 100, 1611-1634.

Bursik, K. (1992). Perceptions of sexual harassment in an academic context. Sex Roles, 27, 401-412.

Bursik, K., \& Gefter, J. (2011). Still stable after all these years: Perception of sexual harassment in academic contexts. Journal of Social Psychology, 151, 331-349.

Cassese, E. (2020). Straying from the flock: A look at how Americans' gender and religious identities cross-pressure partisanship. Political Research Quarterly, 73, 169-183.

Cassese, E., \& Barnes, T. (2018). Reconciling sexism and women's support for republican candidates. Political Behavior, 41, 677-700.

Cassese, E., \& Holman, M. (2018). Party and gender stereotypes in campaign attacks. Political Behavior, 40, 785-807.

Cassese, E., \& Holman, M. (2019). Playing the woman card: Ambivalent sexism in the 2016 U.S. presidential race. Political Behavior, 40, 55-74.

Castle, J., Jenkins, S., Orbals, C., Poloni-Staudinger, L., \& Cherie Strachan, J. (2020). The effect of the \#MeToo movement on political engagement and ambition in 2018. Political Research Quarterly, 73, 926-941.

Conover, P. (1988). Feminists and the gender gap. Journal of Politics, 50, 985-1010.

Cook, E., \& Wilcox, C. (1991). Feminism and the gender gap-A second look. Journal of Politics, 53, 1111-1122.

Cooperman, R., Shufeldt, G, \& Conger, K. (2021) The life of the parties: Party activists and the 2016 Presidential Election. Party Politics.

Cortina, L., \& Berdahl, J. (2008). Sexual harassment in organizations. In SAGE Handbook of Organizational Behavior. Sage.

Cossette, P., \& Craig, S. (2020). Politicians behaving badly: Men, women, and the politics of sexual harassment. Routledge.

Costa, M., Briggs, T., Chahal, A., Fried, J., Garg, R., Kriz, S., Lei, L., Milne, A., \& Slayton, J. (2020). How partisanship and sexism influence voters' reactions to \#MeToo scandals. Research and Politics, 7,3 .

Craig, S. C., \& Cossette, P. (2020). Eye of the beholder: Partisanship, identity, and the politics of sexual harassment. Political Behavior. https://doi.org/10.1007/s11109-020-09631-4

de Beauvoir, S. (1949). The Second Sex. Knopf.

Doherty, D., Dowling, C., \& Miller, M. (2011). Are financial or moral scandals worse? PS: Political Science and Politics, 44, 749-757.

Dolan, K. (2014). When does gender matter? Oxford University Press.

Eagly, A., \& Carli, L. (2018). Women and the labyrinth of leadership. In W. Rosenbach, R. Taylor, \& M. Youndt (Eds.), Contemporary issues in leadership. New York: Routledge.

Feldblum, C., \& Lipnic, V. (2016). Select task force on the study of harassment in the workplace. U.S. EEOC.

Fenno, R. (1978). Home style. Longman.

Fiske, S., \& Glick, P. (1995). Ambivalence and stereotypes cause sexual harassment. Journal of Social Issues, 51, 97-115.

Fitzgerald, L., Drasgow, F., Hulin, C., Gelfand, M., \& Magley, V. (1997). Antecedents and consequences of sexual harassment in organizations. Journal of Applied Psychology, 82, 578-589.

Fitzgerald, L., Gelfand, M., \& Drascow, F. (1995). Measuring sexual harassment. Basic and Applied Social Psychology, 17, 425-445.

Grose, C. R., \& Oppenheimer, B. I. (2007). The Iraq war, partisanship, and candidate attributes: Variation in Partisan Swing in the 2006 U.S. house elections. Legislative Studies Quarterly, 32, 531-557.

Hayes, D. (2011). When gender and party collide: Stereotyping in candidate trait attribution. Politics and Gender, 7, 133-165.

Herrnson, P., Lay, C., \& Stokes, A. K. (2003). Women Running as women: Candidate gender, campaign issues and voter-targeting strategies. Journal of Politics, 65, 244-255. 
Hetherington, M., \& Weiler, J. (2009). Authoritarianism and polarization in American politics. Cambridge University Press.

Hill, C., \& Kearl, H. (2011). Crossing the line: Sexual harassment at school. American Association of University Women.

Huddy, L., Cassese, E., \& Lizotte, M.-K. (2008). Sources of political unity and disunity among women. In L. D. Whitaker (Ed.), Voting the gender gap. University of Illinois Press.

Jensen, I., \& Gutek, B. (1982). Attributions and assignment of responsibility in sexual harassment. Journal of Social Issues, 38, 121-136.

Junn, J. (2017). The trump majority: White womanhood and the making of female voters in the U.S. Politics, Groups and Identities, 5, 343-352.

Junn, J., \& Masuoka, N. (2020). The gender gap is a race gap: Women voters in U.S. Presidential Elections. Perspectives on Politics., 18(4), 1135-1145.

Kaufmann, K., \& Petrocik, J. (1999). The changing politics of American men: Understanding the sources of the gender gap. American Journal of Political Science, 43, 864-887.

Klar, S. (2018). When common identities decrease trust: An experimental study of partisan women. American Journal of Political Science, 62, 610-622.

Klein, E. (1984). Gender Politics. Harvard University Press.

Lavine, H., \& Gschwend, T. (2007). Issues, Party and Character. British Journal of Political Science, 37, $139-163$.

Layman, G. (2001). The great divide. Columbia University Press.

Leeper, T. J., \& Slothuus, R. (2014). Political parties, motivated reasoning, and public opinion formation. Advances in Political Psychology, 35, 129-156.

Levendusky, M. (2009). The partisan sort. University of Chicago Press.

Lodge, M., \& Taber, C. (2013). The rationalizing voter. Cambridge University Press.

Manne, K. (2018). Down girl: The logic of misogyny. Oxford University Press.

Ondercin, H. (2017). Who is responsible for the gender gap? Political Research Quarterly., 70, 749-761.

Paolino, P. (1995). Group-salient issues and group representation: Support for women candidates in the 1992 senate elections. American Journal of Political Science, 39, 294-313.

Pina, A., \& Gannon, T. (2012). An overview of the literature on antecedents, perceptions and behavioral consequences of sexual harassment. Journal of Sexual Aggression, 18, 209-232.

Prior, J., \& Day, J. (1988). Interpretations of sexual harassment: An attributional analysis. Sex Roles, 18, $405-417$.

Ratkovic, M. (2021). Subgroup analysis: pitfalls, promise, and honesty. In J. Druckman \& D. Green (Eds.), Handbook of experimental political science. Cambridge University Press.

Ridgeway, C. (2011). Framed by gender. Oxford University Press.

Ridgeway, C., \& Nakagawa, S. (2017). Is deference the price of being seen as reasonable? How status hierarchies incentivize acceptance of low status. Social Psychology Quarterly, 80, 132-152.

Rothschild, Z., Keefer, L., \& Hauri, J. (2021). Defensive partisanship? Evidence that in-party scandals increase out-party hostility. Political Psychology, 42, 3-21.

Schneider, M., \& Bos, A. (2016). The interplay of candidate party and gender in evaluations of political candidates. Journal of Women, Politics, and Policy, 37, 274-294.

Thomsen, D. (2014). Ideological moderates won't run: How party fit matters for partisan polarization in congress. Journal of Politics, 76, 786-797.

Tien, C. (2017). The racial gap in voting among women. New Political Science, 39, 651-669.

Valentino, N., Wayne, C., \& Oceno, M. (2018). Mobilizing sexism: The interaction of emotion and gender attitudes in the 2016 Presidential Election. Public Opinion Quarterly, 82, 799-821.

Winter, N. (2010). Masculine republicans and feminine democrats: Gender and americans' explicit images of the political parties. Political Behavior, 32, 587-618.

Wolbrecht, C. (2000). The politics of women's rights. Princeton University Press.

Yoshinaka, A., \& Grose, C. (2008). Ideological hedging in uncertain times. British Journal of Political Science, 41, 765-794.

Young, L. (2000). Feminists and party politics. UBC Press.

Publisher's Note Springer Nature remains neutral with regard to jurisdictional claims in published maps and institutional affiliations. 